\title{
Patient safety management from the perspective of nurses*
}

\author{
Gerenciamento da segurança do paciente sob a ótica dos enfermeiros \\ Gestión de la seguridad del paciente bajo el punto de vista de los enfermeros
}

Lucilena Françolin ${ }^{1}$, Carmen Silvia Gabriel2 ${ }^{2}$, Andrea Bernardes², Ana Elisa Bauer de Camargo Silva ${ }^{3}$, Maria de Fatima Paiva Brito $^{4}$, Juliana Pereira Machado 5

\author{
* Extracted from the dissertation "Gerenciamento \\ da segurança assistencial nos serviços de \\ enfermagem", School of Nursing of Ribeirão \\ Preto, Universidade de São Paulo, 2013. \\ ${ }^{1}$ Quality Manager, Grupo São Lucas, Ribeirão \\ Preto, SP, Brazil. \\ ${ }^{2}$ Associate Professor, Department of General \\ and Specialized Nursing, School of Nursing \\ of Ribeirão Preto, Universidade de São Paulo, \\ Ribeirão Preto, SP, Brazil. \\ ${ }^{3}$ Professor, PhD, Faculty of Nursing, \\ Universidade Federal de Goiás, Goiânia, GO, \\ Brasil. \\ ${ }^{4}$ PhD Student, School of Nursing of Ribeirão \\ Preto, Universidade de São Paulo, Ribeirão Preto, \\ SP, Brazil \\ ${ }^{5}$ Professor, PhD, Faculty of Nursing, Centro \\ Universitário Barão de Mauá, Ribeirão Preto, SP, \\ Brazil.
}

\section{ABSTRACT}

Objective: To evaluate the actions of patient safety management developed in hospitals, from the perspective of nurses. Method: This is a cross-sectional, descriptive study of the survey type. Participants were seven hospitals, in which seven nurse managers and 49 sector coordinator nurses $(n=56)$ answered the instrument prepared by the author. Results: The results showed that $100 \%$ of hospitals have an adverse event reporting system, $71.4 \%$ have a Risk Management Committee and $80 \%$ have discussions about the events. There is agreement that these discussions lead to favorable changes for patient safety in the surveyed institutions. The employees' fear of punishment for their faults, and the underreporting of events were the aspects of greatest weakness found. Conclusion: The institutions should develop organizational policies focused on stimulating event notification and on the implementation of measures directed to a non-punitive organizational culture.

\section{DESCRIPTORS}

Patient Safety; Safety Management; Nursing. 


\section{INTRODUCTION}

According to the World Health Organization $(\mathrm{WHO})^{(1)}$, every year, around the world, tens of millions of patients suffer disabling injuries or death related to errors and failures in health care. In developed countries, a patient in every ten suffers an adverse event while receiving health care in hospitals. In developing countries, the need for research to reveal the numbers on these events is noteworthy. The events can be classified as: reportable circumstance, near-miss, no harm incident, or harmful incident that is also referred to as an adverse event $(\mathrm{AE})^{(2-3)}$.

The lack of patient safety causes 42.7 million incidents with injuries around the world each year. Among this total, two-thirds occur in developing countries and countries in transition, according to a study by the Harvard University ${ }^{(4)}$.

In this context, the analysis of different studies carried out in several countries, such as England, Australia, Canada, Denmark, New Zealand, Portugal, France, Sweden, Spain, Holland and Brazil, showed a high number of cases of adverse events involving a significant portion of hospitalized patients, and concluding that approximately $10 \%$ of hospital admissions result in some type of adverse event. Still in relation to the mentioned places, it was disclosed that the number of preventable adverse events in hospitalizations represent $50 \%$ of cases $^{(5)}$.

Data from the Agency for Healthcare Research and Quality (AHRQ), an organization designated by the US government as the lead agency in supporting research to reduce health gaps, show that more than a decade after its creation and publication of the report To err is buman ${ }^{(6)}$, the US health care system has not evenly benefited from the little progress achieved on the issue of patient safety ${ }^{(7)}$.

A study carried out in Spain has analyzed 245,320 episodes of hospital care with a total cost of $1,308,791,871$ euros. It reached the conclusion that among the total of $\mathrm{pa}^{-}$ tients, 16,782 (6.8\%) have experienced one or more adverse events. When analyzed by groups of diagnoses, the adverse events added average costs of between 5,260 and 11,905 euros in health expenses. Thus, the total cost generated by adverse events was $88,268,906$ euros or $6.7 \%$ of the total health costs. The study data show that adverse events represent a very significant economic impact that can be reversed by improving the quality and safety of health systems ${ }^{(8)}$.

These data are disturbing and cause great impact both nationally and internationally, and justify that the issue of patient safety is considered a priority by the major health organizations around the world.

It is not possible to discuss patient safety without going through the issue of organizational culture of the health institutions, which can be defined as the way a group perceives, thinks and feels ${ }^{(9)}$. If the organizational culture of the institution regarding the management of adverse events is based on punishment and guilt, this may cause failure in reporting these events, making it difficult to build an institutional culture focused on patient safety.

For implementing and incorporating the culture of $\mathrm{pa}^{-}$ tient safety in any health institution, it is necessary that its management and professionals have a high level of commitment, and a strong cohesion spirit among the various departments. These factors are essential to ensure safe care for professionals and patients ${ }^{(10)}$.

In health institutions, nurses act as facilitators in the identification of risks for $\mathrm{AE}$, which is a key element in this process due to their assistance role. As the nurses take their leadership roles with the team, there is evidence of improved care ${ }^{(11)}$, therefore, they should report, compare and measure the facts and consequences of $\mathrm{AE}$. In addition, the nurses are technically responsible for the nursing staff with their class council, and will respond to potential lawsuits related to the occurrence of adverse events.

An event is more likely to be reported if it has caused harm to the patient. As the nurses are those with greater knowledge of the AE reporting system of the institution, they are also the professionals who most report the events ${ }^{(12)}$.

All efforts to improve quality in health and the increasing research on patient safety corroborate what is presented in the National Patient Safety Program (PNSP - Programa Nacional de Segurança do Paciente), which lists the specific objective of production, systematization and dissemination of knowledge on patient safety ${ }^{(13)}$. These facts justify this study, which questions what safety management actions have been adopted in hospitals.

In this perspective, the present study aimed to evaluate the actions of patient safety management developed in hospitals, from the perspective of nurses.

\section{METHOD}

This is a descriptive study, with quantitative approach and cross-sectional design of the Survey type. Data were collected through the application of two structured instruments: one for the nurse managers (NM) and another one for the coordinators, prepared by the principal investigator, who sought to identify and evaluate the patient safety management actions developed in the respective institutions.

The study was conducted in the city of Ribeirão Preto, state of São Paulo (SP) and proposed for all the 15 hospitals in the city, including governmental and private institutions and non-profit organizations. Among all of them, seven (46.7\%) agreed to participate, of which six (85.7\%) were general hospitals and one was a (14.3\%) specialized hospital. Regarding the care complexity, three (42.9\%) are ranked as high complexity and four (57.1\%) of medium complexity, accounting together for about $30 \%$ of the total hospital beds capacity in the city.

The research included the nurse managers of the institutions and the nurse coordinators of the areas of care or support to care who were not on vacation or sick leave during the study period.

The invitation was addressed to the NM, who pointed the respective coordinators or leaders of the areas of care and support to participate in the study. After selection, the study had 56 participants, of which seven $(12.5 \%)$ were NM and $49(87.5 \%)$ were nurse coordinators.

The project was approved by the Research Ethics Committee of the School of Nursing of Ribeirão Preto, 
Universidade de São Paulo, under protocol CAAE: 00803212.2.0000.5393. All participants voluntarily agreed to participate by signing the Free and Informed Consent. Each participant was interviewed once in the institution, during working hours, with prior appointment.

The data collection period was between August and September 2012, through interviews. The instrument went through face, content and semantics validation by five judges, researchers and nurses working in the area of patient safety, who received the questionnaire, analyzed it and suggested adjustments, inclusion and exclusion of terms. Each evaluation was analyzed carefully by two researchers independently. The final version of the instrument included closed questions concerning the characterization of professionals and the theme of AE, its occurrence in the institution, causal factors, behaviors adopted and preventive measures.

The following variables related to patient safety management directed at the NM were considered: the existence of notification systems, the existence of a risk management committee, nurse participation in this committee, the presence of discussions on $\mathrm{AE}$ in the committee, the form of identifying $\mathrm{AE}$, and the description of the tools used to evaluate the risks of $\mathrm{AE}$.

The listed variables directed to the coordinating nurses were the following: notification frequency of $\mathrm{AE}$ or near miss; identification of elements that promote the safety culture in the institutions and the fear of employees in face of the consequences of $\mathrm{AE}$ notification; the existence of multidisciplinary discussions on ways to prevent $\mathrm{AE}$ and an understanding that discussions on $\mathrm{AE}$ promote positive changes in the teams.

A common variable to nurse managers and coordinators about the support of senior management to implement patient safety initiatives was analyzed.

The results were entered in a Microsoft Excel ${ }^{\circledR}$ version 2007 database and analyzed using descriptive statistics, with relative and absolute frequencies and percentage, using the Statistical Package For The Social Science ${ }^{\circledR}$ (SPSS) version 15.0.

\section{RESULTS}

The study had 56 participants (seven NM and 49 coordinator nurses) for assessing the actions developed in hospitals from the perspective of nurses, guided by the management of patient safety, in relation to the notification system, the existence and presence of nurses in the risk management committee, and the tools used for identifying and preventing risks.

As for the characterization of the sample, there is a predominance of females, a feature observed in six (85.7\%) of the $\mathrm{NM}$ and 41 (87.7\%) of the coordinator nurses. In relation to further training, six (85.7\%) NM and 39 (79.6\%) coordinator nurses have post-graduation courses, with predominance of the lato sensu modality (specialization) in five (83.3\%) of the NM and in $32(82,0 \%)$ of the coordinator nurses.

In relation to the profile of the hospitals, only two (28.6\%) have some kind of quality program implemented. All hospitals have an internal system of AE notification, with predominance of the electronic form of notification (Table 1).
Table 1 - AE notification system, risk management committee and $\mathrm{AE}$ agreements in the surveyed institutions, according to the reports of NM - Ribeirão Preto, SP, 2012.

\begin{tabular}{llc}
\hline Variables & $\mathbf{f}$ & $\%$ \\
\hline There is an internal AE notification system & & \\
Yes & 07 & 100.0 \\
Form of AE notification & 04 & 57.1 \\
Electronic & 03 & 42.9 \\
Manual (written) & & \\
There is a risk management committee & 05 & 71.4 \\
Yes & 02 & 28.6 \\
No & & \\
There are nurses integrating the committee & 05 & 71.4 \\
Yes & 02 & 28.6 \\
There is no committee & & \\
The committee discusses the notified AE & 04 & 57.1 \\
Yes & 01 & 14.3 \\
No & 02 & 28.6 \\
There is no committee &
\end{tabular}

f: frequency of responses.

Note: $(n=7)$

According to the NM, in relation to the way adopted for identifying care risks, six (85.7\%) stated to adopt at least a tool for risk assessment, and only one professional (14.3\%) reported not formally adopting any kind of tool.

The following tools used for risk assessment stand out, according to the NM: the clinical audit, adopted by four (57.1\%) institutions; the Braden Scale and the NAS (Nursing Activities Score), both adopted by three (42.9\%) institutions (Table 2).

Table 2 - Tools adopted for identification of risks and care complexity, according to the NM - Ribeirão Preto, SP, 2012.

\begin{tabular}{lcc}
\hline Variables & f & \% \\
\hline Clinical Audit & 04 & 57.1 \\
Braden Scale & 03 & 42.9 \\
NAS (Nursing Activities Score) & 03 & 42.9 \\
Perroca Classification System & 02 & 28.6 \\
Norton Scale & 01 & 14.3 \\
MEWS Score (Modified Early Warning Score) & 01 & 14.3 \\
Fugulin Classification & 01 & 14.3 \\
TISS (Therapeutic Intervention Scoring System ) & 01 & 14.3 \\
No instrument is used & 01 & 14.3 \\
\hline
\end{tabular}

f: frequency of responses.

Note: $(n=7)$

Regarding the frequency of AE notification, according to the coordinator nurses, $30(81.7 \%)$ participants mentioned notifying cases of $\mathrm{AE}$ with potential harm to patients, and $43(87.7 \%)$ participants notify the occurrence of an $\mathrm{AE}$ that affects the patient without causing harm. Even when the AE affects the patient, it was observed that seven $(14.3 \%)$ coordinators never or rarely report it (Table 3 ). 
Table 3 - Notification of AE and near miss done by coordinator nurses -Ribeirão Preto, SP, 2012.

\begin{tabular}{lcc}
\hline Variables & $\mathbf{f}$ & $\mathbf{\%}$ \\
\hline Notification of a near miss. & & \\
Never & 01 & 2.0 \\
Rarely & 11 & 22.5 \\
Sometimes & 13 & 26.5 \\
Almost always & 17 & 34.7 \\
Always & 07 & 14.3
\end{tabular}

Notification of an AE that affects the patient, but has no harmful potential.

$\begin{array}{lcc}\text { Never } & 01 & 2.0 \\ \text { Rarely } & 02 & 4.1 \\ \text { Sometimes } & 06 & 12.2 \\ \text { Almost always } & 14 & 28.6 \\ \text { Always } & 26 & 53.1\end{array}$

Notification of an AE that affects patients, has harmful potential, but does not cause them any harm.

\begin{tabular}{lll} 
Never & 01 & 2.0 \\
Rarely & 03 & 6.3 \\
\hline
\end{tabular}

f: frequency of responses.

Note: $(n=49)$

According to the coordinator nurses, 44 (89.8\%) agree that most of the staff is afraid of the notification consequences and $44(89.8 \%)$ coordinators agree that discussions about the errors have led to positive changes (Table 4).

Table 4 - Coordinator nurses' perspective about the dissemination of safety culture of the surveyed hospitals - Ribeirão Preto, SP, 2012.

\begin{tabular}{lcc}
\hline Variables & $\mathbf{f}$ & $\%$ \\
\hline $\begin{array}{l}\text { Employees are afraid that their mistakes appear in their functional } \\
\text { records }\end{array}$ & 04 & 8,2 \\
Disagree & 01 & 2,0 \\
Neutral & 31 & 63,3 \\
Agree & 13 & 26,5 \\
Strongly agree & unit & \\
The forms of preventing errors are discussed at the & 02 & 4,2 \\
Rarely & 06 & 12,2 \\
Sometimes & 22 & 44,9 \\
Almost always & 19 & 38,8 \\
Always & 04 & 8,2 \\
Discussions on the errors have led to positive changes \\
Strongly disagree & 01 & 59,2 \\
Neutral & 04 & 30,6 \\
Agree & 15 & 29 \\
Strongly agree & & \\
\hline
\end{tabular}

f: frequency of responses. Note: $(n=49)$

When asked if there is support from the administration for the implementation of safety management in the institutions, there was unanimous agreement among the NM (Figure 1).

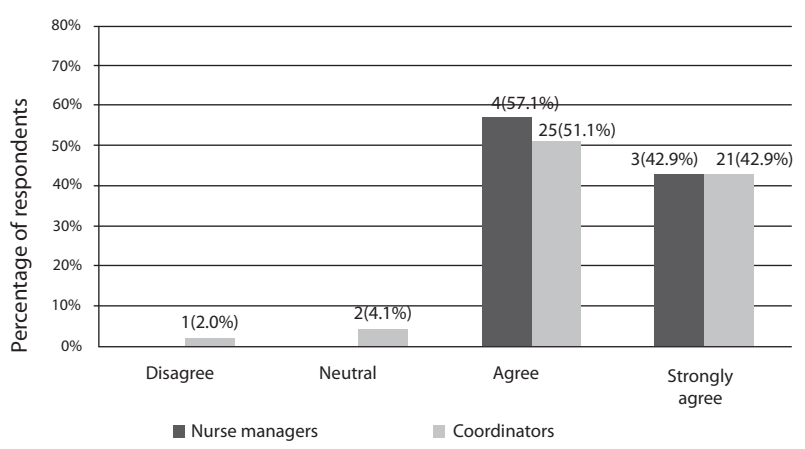

Figure 1 - Opinion of the nurse managers $(n=7)$ and coordinator nurses $(n=49)$ in relation to administration support to implement safety measures - Ribeirão Preto, SP, 2012.

\section{DISCUSSION}

The present study showed that in the sample, actions are being developed in hospitals, oriented by patient safety management from the perspective of nurses.

Data from the Federal Nursing Council ${ }^{(14)}$ show that nursing professionals are mostly female, confirming the results of this study.

The results showed that all institutions have notified the $\mathrm{AE}$, and the majority uses the electronic system, revealing a very positive perspective, given the recommendations of the DRC resolution number 36 of July $25,2013^{(15)}$. It states that establishing safety improvements is not possible without knowledge of the AE.

The results also showed the fear of professionals in relation to punitive measures related to AE notification, which should be considered a point of attention and improvement. Individuals should be able to report errors without fear of punishment or embarrassment. They must be convinced that the response to the event will not be Who failed? but rather What happened?(16), emphasizing that notifications can reduce the incidence of errors. The existence of a non-punitive and supportive environment is essential for the notification of situations of risk/errors and near misses, since the majority of errors are due to the system, and not just human errors ${ }^{(17)}$.

This study showed that the discussions on AE were considered positive in seeking improvements, and by understanding that the detection of these events can serve as a basis for decision making and planning of patient safety from the analysis, monitoring, minimization and prevention of incidents that may cause $\mathrm{AE}^{(18-19)}$. In order to face the $\mathrm{AE}$, errors and incidents in health services that put patient safety at risk, it is necessary to know the scope and magnitude of their occurrences ${ }^{(20)}$, which go far beyond the creation of a computerized system for notification of events.

In addition to analyzing risks, the identification and report of AE may promote the adoption of preventive measures by health professionals for possible corrections, aiming at minimizing or eliminating the occurrence of such events, and also follow the development of actions taken to improve the health practice ${ }^{(21)}$.

The results showed that the notifications are resultant from AE that could affect patients, but did not affect. Similarly, another study ${ }^{(22)}$ has demonstrated reports of $\mathrm{AE}$ in 
the occurrence of errors, mistakes or failures when there was no harm to patients. This fact confirms that workers are afraid of reporting errors when the patient is affected.

It is important that the institutions encourage notifications with complete data. This way, control strategies can be developed to prevent new occurrences, directly influencing the quality of care. For the effective occurrence of notifications, professionals must be constantly oriented on the importance of the records, which should be correct and complete, with simple forms, easy to understand and fill out ${ }^{(23)}$.

When identifying the risks that affect patient safety, arises the need to analyze them, which is a systematic process of identification, analysis and treatment of causes ${ }^{(20)}$. The results of the present study converge in this sense by emphasizing the actions related to the discussion of $\mathrm{AE}$, with presence of nurses in risk management committees and the perception of positive changes resulting from such actions.

The discussion of $\mathrm{AE}$ in a risk management committee formed by a multidisciplinary team, with the objective of developing strategies based on normative and regulatory requirements, may favor the minimization of errors ${ }^{(24)}$ and promote health education actions in order to prevent damages related to assistance that affect patient safety. This is a strategy that health institutions should use in order to help the investigation of adverse events, for their anticipation and minimization ${ }^{(25)}$.

The greatest contribution of this study is producing a diagnosis of the actions of patient safety management in a regional center for health related to hospital services.

The evaluation of actions of patient safety management restricted to the perspective of nurses with a leadership position is considered a limitation of this study.

\section{CONCLUSION}

This study achieved its objectives because it evaluated the actions developed in hospitals from the perspective of nurses, guided by patient safety management and showing several positive and relevant aspects in the risk management processes of the surveyed institutions. One of such processes refers to the presence of a notification system of $\mathrm{AE}$ in all institutions, which facilitates the identification of weaknesses.

The study also shows that most hospitals have an established Risk Management Committee with participating nurses. In addition, several nursing services already use scores and scales to predict care risks, which helps in care planning. Another important aspect is that most coordinators stated that the errors have led to positive changes in the institutions.

Among the weaknesses found, the culture of fear was evident. The employees fear their errors will appear in their professional records. Another evidence was the underreporting of $\mathrm{AE}$, even the events that have affected the patients.

Actions aimed at optimization of patient care shall be developed urgently to reduce errors caused by system failures. In this respect, the quality programs can be tools to help health institutions to learn more about their services, identifying their weaknesses, implementing more consistent, safe and agile actions, and providing a better use of the available resources, avoiding waste and allowing their better application.

The institutions should reflect critically on the role played by managers, as their strategic decisions include people management, facility planning, developing operational procedures, choice of equipment, and all other decisions that define the system structure.

The improvement of the nurses' skills and knowledge is a key factor to increase quality of care and consequently, patient safety. In this context, it is necessary to invest in professional training and safe care provision for health services users.

The high level of agreement about the senior administration support in safety management of institutions is an important factor. The correction of the weaknesses certainly involves not only procedural improvements, but also environmental and technological improvements that require investments in order to happen.

The diagnostic of risk management presented can support hospital service managers to implement measures capable of improving safety management in institutions, since quality and safety are inseparable attributes.

\section{RESUMO}

Objetivo: Avaliar sob a ótica dos enfermeiros, as ações de gerenciamento da segurança dos pacientes desenvolvidas em instituições hospitalares. Método: Trata-se de um estudo transversal, descritivo, tipo Survey. Participaram do estudo sete hospitais nos quais sete enfermeiros responsáveis e 49 enfermeiros coordenadores de setores $(n=56)$ responderam ao instrumento elaborado pelo autor. Resultados: Os resultados evidenciaram que $100 \%$ dos hospitais possuem sistema de notificação de eventos adversos, $71,4 \%$ possuem Comissão de Gerenciamento de Riscos, $80 \%$ realizam discussão dos eventos, havendo consenso de que tais discussões levam a mudanças favoráveis à segurança do paciente nas instituições pesquisadas. O receio dos colaboradores por punição frente às suas falhas e a subnotificação dos eventos foram os aspectos de maior fragilidade encontrados. Conclusão: As instituições devem desenvolver políticas organizacionais focadas no estímulo à notificação de eventos e na implementação de medidas que direcionem para uma cultura organizacional não punitiva.

\section{DESCRITORES}

Segurança do Paciente; Gerenciamento de Segurança; Enfermagem. 


\section{RESUMEN}

Objetivo: Evaluar bajo el punto de vista de los enfermeros las acciones de gestión de la seguridad de los pacientes desarrolladas en instituciones hospitalarias. Método: Se trata de un estudio transversal, descriptivo, tipo Survey. Participaron del estudio siete hospitales en los que siete enfermeros responsables y 49 enfermeros coordinadores de sectores $(n=56)$ respondieron al instrumento elaborado por el autor. Resultados: Los resultados evidenciaron que el 100\% de los hospitales tiene sistema de notificación de eventos adversos, el 71,4\% tiene Comisión de Gestión de Riesgos, el 80\% llevó a cabo la discusión de los eventos, habiendo consenso de que dichas discusiones conducen a cambios favorables a la seguridad del paciente en las instituciones investigadas. El recelo de los colaboradores por punición ante sus fallos y la subnotificación de los eventos fueron los aspectos de mayor fragilidad encontrados. Conclusión: Las instituciones deben desarrollar políticas organizacionales enfocadas en el estímulo a la notificación de eventos y la implantación de medidas que remitan a una cultura organizacional no punitiva.

\section{DESCRIPTORES}

Seguridad del Paciente; Administración de la Seguridad; Enfermería.

\section{REFERENCES}

1. World Health Organization. Summary of the evidence on patient safety: implications for research. Geneva: WHO; 2008.

2. World Health Organization. The conceptual framework for the international classification for patient safety (ICPS). Geneva: WHO; 2009.

3. Runciman W, Hibbert P, Thomson R, Van Der Schaaf T, Sherman H, Lewalle P. Towards an International Classification for Patient Safety: key concepts and terms. Int J Qual Health Care. 2009;21(1):18-26.

4. Jha AK, Larizgoitia I, Audera-Lopez C, Prasopa-Plaizier N, Waters H, Bates DW. The global burden of unsafe medical care: analytic modelling of observational studies. BMJ Qual Saf [Internet]. 2013 [cited 2014 Mar 21];22(10):809-15. Available from: http//www.qualitysafety. bmj.com/content/22/10/809.full.pdf+html

5. de Vries EN, Ramrattan MA, Smorenburg SM, Gouma DJ, Boermeester MA. The incidence and nature of in-hospital adverse events: a systematic review. Qual Saf Health Care [internet]. 2008 [cited 2014 Mar 21];17(3):216-23. Available from: http://www.ncbi.nlm.nih. gov/pmc/articles/PMC2569153/

6. Kohn LT, Corrigan JM, Donaldson MS; Committee on Quality of Health Care in America; Institute of Medicine. To err is human: Building a Safer Health System. Washington: National Academy Press; 2000.

7. Agency for Healthcare Research and Quality. A decade of evidence, design, and implementation: advancing patient safety [Internet]. Rockville: AHRQ; 2012 [cited 2014 Mar 21]. Available from: http//www.ahrq.gov/professionals/quality-patient-safety/patient-safety-resources/ advancing-patient-safety/index.html

8. Allué N, Chiarello P, Bernal Delgado E, Castells X, Giraldo P, Martínez N, et al. Impacto económico de los eventos adversos em los hospitales españoles a partir del conjunto mínimo básico de datos. Gac Sanit. 2014;28(1):48-54.

9. Schein E. Organizational culture and leadership. 3nd ed. San Francisco: Jossey-Bass; 2004.

10. Carvalho RE, Cassiani SH. Cross-cultural adaptation of the Safety Attitudes Questionnaire - Short Form 2006 for Brazil. Rev Lat Am Enfermagem. 2012;20(3):575-82.

11. Laschinger HK, Smith LM. The influence of authentic leadership and empowerment on new-graduate nurses' perceptions of interprofessional collaboration. J Nurs Adm. 2013;43(1):24-9.

12. Kreckler S, Catchpole K, McCulloch P, Handa A. Factors influencing incident reporting in surgical care. Qual Saf Health Care. 2009;18(2):116-20.

13. Brasil. Ministério da Saúde. Portaria n. 529, de $1^{\circ}$ de abril de 2013. Institui o Programa Nacional de Segurança do Paciente (PNSP) [Internet]. Brasília; 2013 [citado 2014 mar. 21]. Disponível em: http://bvsms.saude.gov.br/bvs/saudelegis/gm/2013/prt0529_01_04_2013.html

14. Conselho Federal de Enfermagem (COFEN). Análise de dados dos profissionais de enfermagem existentes nos Conselhos Regionais. Brasília: Departamento de Tecnologia da Informação; 2011.

15. Brasil. Ministério da Saúde. Resolução da Diretoria Colegiada n.36, de 25 de julho de 2013. Institui ações para a segurança do paciente em serviços de saúde e dá outras providências [Internet]. Brasília; 2013 [citado 2014 mar. 21]. Disponível em: http://bvsms.saude.gov.br/ bvs/saudelegis/anvisa/2013/rdc0036_25_07_2013.html

16. Leape L, Berwick D, Clancy C, Conway J, Gluck P, Guest J, et al. Transforming healthcare: a safety imperative. Qual Saf Health Care. 2009; 18(6):424-8.

17. McCannon CJ, Hackbarth AD, Griffin FA. Miles to go: an introduction to the 5 Million Lives Campaign. Jt Comm J Qual Patient Saf. 2007;33(8):477-84.

18. Silva RC, Ferreira MA. Características dos enfermeiros de uma unidade tecnológica: implicações para o cuidado de enfermagem. Rev Bras Enferm. 2011;64(1):98-105.

19. Hinrichsen SL, Oliveira CLF, Campos MA, Possas LCM, Sabino G, Vilella T. Gestão da qualidade e dos riscos na segurança do paciente: estudo-piloto. RAHIS. 2011(7):10-7.

20. Adhikari R, Tocher J, Smith P, Corcoran J, MacArthur J. A multi-disciplinary approach to medication safety and the implication for nursing education and practice. Nurse Educ Today. 2014;34(2):185-90.

21. Carneiro FS, Bezerra ALQ, Silva AEBC, Souza LP, Paranaguá TTB, Branquinho NCSS. Eventos adversos na clínica cirúrgica de um hospital universitário: instrumento de avaliação da qualidade. Rev Enferm UERJ. 2011;19(2):204-11. 
22. Reis CT, Laguardia J, Martins M. Translation and cross-cultural adaptation of the Brazilian version of the Hospital Survey on Patient Safety Culture: initial stage. Cad Saúde Pública. 2012;28(11):2199-210.

23. Bezerra ALQ, Silva AEBC, Branquinho NCSS, Paranaguá TTB. Análise de queixas técnicas e eventos adversos notificados em um hospital sentinela. Rev Enferm UERJ. 2009;17(4):467-72.

24. Battaglia JN, Lis JE, Chui MA. Evaluation of a patient perspective module in a required medication safety and quality course at a college of pharmacy. Inov Pharm. 2013;4(1):102.

25. Manias E, Gerdtz M, Williams A, Dooley M. Complexities of medicines safety: communicating about managing medicines at transition points of care across emergency departments and medical wards. J Clin Nurs. 2014 Sept 11. [Epub ahead of print]. 